\title{
Molecular Cloning of Equine (Thoroughbred) Myostatin cDNA and Detection of Myostatin Precursor Proteins in the Serum
}

\author{
Tohru HOSOYAMA ${ }^{1)}$, Shigeo KAWADA ${ }^{2)}$, Ryosuke OSHIUMI ${ }^{3)}$, \\ Sachie YONEDA ${ }^{3)}$, Chie SOETA ${ }^{4}$, Keitaro YAMANOUCHI ${ }^{5}$, \\ Telhisa HASEGAWA ${ }^{6}$, Nobushige ISHIDA $^{6}$, Harutaka MUKOYAMA ${ }^{6}$, \\ Naokata ISHII') and Chikashi TACHI ${ }^{3)}$
}

${ }^{1)}$ Department of Biology, Faculty of Science, Graduate School of Science and Technology, Chiba University, Yayoi-cho, Inage-ku, Chiba 263-8522, 2) Department of Life Sciences, Graduate School of Arts and Sciences, The University of Tokyo, Meguro-ku, Tokyo 153, 3) Laboratory of Developmental and Reproductive Biotechnology, Department of Animal Resource Sciences, School of Veterinary Medicine and Life Sciences, Azabu University, Sagamihara-shi 229-8501,4)Center for Experimental Medicine, Institute of Medical Science, The University of Tokyo, Minato-ku, Tokyo 108-0071, 5) Laboratory of Veterinay Physiology, Department of Veterinary Medicine, Graduate School of Agriculture and Life Sciences, The University of Tokyo, Tokyo 113-8657, ${ }^{6}$ Laboratory of Molecular and Cellular Biology, Equine Research Institute, Japan Racing Horse Association, Utsunomiya-shi 320-0856, Japan

\begin{abstract}
Growth/Differentiation Factor 8, or GDF-8, is a member of the TGF- $\beta$ family and is expressed specifically in myogenic precursor cells of the myotome during development as well as in adult axial and paraxial muscles of the mouse. It acts as a negative regulator of skeletal muscle mass, and is known as myostatin. As a part of our studies to elucidate mechanisms underlying the growth of skeletal muscle mass due to physical training in mammals including horses and humans, we isolated and cloned myostatin cDNA from equine (Thoroughbred) skeletal muscles by an RT-PCR method. The base sequence of the entire coding region of equine myostatin cDNA (DDBJ accession no. AB033541) exhibited a high degree of homology to those of other species so far reported. In the deduced amino acid sequence, 4 amino acid positions were unique to the equine myostatin, i. e., $\mathrm{Val}^{15}$ instead of Met, Leu ${ }^{18}$ instead of Val or Ala, Ala ${ }^{201}$ instead of Thr, Arg ${ }^{244}$ instead of Gly or Glu in other species. Western blot analysis of the equine skeletal muscles using anti-myostatin antibody, yielded 3 immunoreactive bands, i. e., 26,45 and $50 \mathrm{kDa}$. The band at approximately $26 \mathrm{kDa}$ probably represents mature myostatin and another at approximately $50 \mathrm{kDa}$ corresponds in size to the unprocessed precursor myostatin proteins reported in the literature. Western blot analysis of equine sera of 2 independent breeds, Thoroughbred and Kiso-uma, revealed the possible presence of precursor myostatin proteins at relatively high levels. The molecular identity and the biological significance of serum myostatin immunoreactivities remain to be clarified.
\end{abstract}

Key words: myostatin, muscle, cDNA, Western blotting, serum, horse

(J. Reprod. Dev. 48: 335-342, 2002)

G rowth/Differentiation Factor 8, or GDF-8, is a member of the TGF- $\beta$ family and is expressed specifically in myogenic precursor cells of the myotome compartment of developing somites as

Accepted for publication: February 26, 2002

Correspondence: $\mathrm{C}$. Tachi 
well as in adult axial and paraxial muscles of the mouse [1]. The targeted destruction of the gene coding for GDF-8 in mice revealed its function as a negative regulator of skeletal muscle mass; the GDF-8 null mice exhibited a dramatic and widespread increase in skeletal muscle mass causing them to weigh 2-3 times more than wildtype mice [1]. Hence, GDF-8 is named myostatin and the gene coding for it, Mstn [1]. Later a mouse strain with a phenotype of hypermuscularity, Compact (Cmpt), was identified to carry a mutant Mstn gene which was mapped to Chromosome 1 [2].

Studies on the double-muscling phenotype in Belgian Blue and Piedmontese cattle, revealed that the bovine myostatin gene was mapped to the same chromosomal position as the muscular hypertrophy locus, $m h$, and that these cattle breeds had mutations in the myostatin coding sequence $[3$, 4]. Thus, Piedmontese double-muscled cattle had a $\mathrm{G}$ to A transition in exon 3, resulting in a cysteine to tyrosine substitution in the mature myostatin protein after processing. Belgian Blue cattle, on the other hand had a frame-shift in the C-terminal regions caused by an 11-nucleotide deletion in exon 3 [5-7].

The myostatin gene is highly conserved among the various vertebrate species so far examined, suggesting that the biological function of myostatin is crucial in skeletal muscle development of vertebrates [7, 8]. Lee and McPherron [9] proposed that myostatin may be responsible for the regulation of skeletal muscle mass as a putative negative regulator of tissue growth, i. e., chalone, the existence of which had been postulated originally by Bullough [10].

Myostatin shares several common structural features with other members of the TGF- $\beta$ superfamily: 1) the presence of a hydrophobic core of amino acids near the $\mathrm{N}$-terminus that functions as a secretory signal; 2 ) the formation of disulphidelinked dimers containing subunits of 110-140 amino acids as their biologically active forms; and 3) synthesis of its subunits as the C-terminal portion of a larger precursor which is cleaved at the proteolytic processing site [1].

Recently Wehling et al. [11] demonstrated that myostatin expression is modulated in fully differentiated, non-pathological hind limb muscles of Wistar rats in a manner inversely related to changes in the muscle mass. Thus, atrophy of plantaris muscles induced by 10 days of unloading was accompanied by a $16 \%$ decrease in total mass of the muscle, a $110 \%$ increase in myostatin mRNA and a $37 \%$ increase in myostatin protein levels [11]. The elevated levels of myostatin expression, however, were not a sufficient cause for, but rather a result of muscle mass loss [11, 12].

As a part of our studies to elucidate mechanisms underlying the growth of skeletal muscle mass due to physical training in mammals including horses and humans, in order to determine a basis for developing the training methods optimal for the muscular development, we cloned equine myostatin cDNA and examined the expression of myostatin immunoreactivities in muscles and sera.

\section{Materials and Methods}

\section{Collection of tissue and blood samples}

Skeletal muscles were collected from fetal and adult Thoroughbred horses. Specimens of M. rectus abdominis were collected from fetuses whereas tissue samples of $\mathrm{M}$. semitendinosus and semimembranosus, M.splenius, M. gluteus medius were obtained from adult horses. The obtained specimens were rapidly frozen in liquid nitrogen, and stored at $-80 \mathrm{C}$ until use. Blood samples were collected from the carotid arteries of Thoroughbred and Kiso-uma horses, centrifuged at 3,000 rpm at 4 $\mathrm{C}$, and stored at $-80 \mathrm{C}$ until use.

\section{Extraction of RNA and RT-PCR analysis}

Total RNA was extracted from the muscles using an ISOGEN kit (Nippon Gene, Toyama-shi) and mRNA was purified from the total RNA using Oligotex dT30 super (Takara, Ohtsu-shi) according to the procedures described by the manufacturer. The mRNA (200 ng) was reverse-transcribed into first strand cDNA using Super Script (Gibco-BRL, NY) in a reaction volume of $20 \mu \mathrm{l}$ as recommended by the manufacturer. The reaction mixture contained $5 \times$ first strand buffer, $10 \mathrm{mM}$ dNTP mixture, $0.1 \mathrm{M}$ DTT, $0.5 \mathrm{mM}$ oligo-dT primer and 200 U Super Script. For PCR amplification, 2 primer sets designed by Grobet et al. [4] for the bovine myostatin sequence were used. The primer sequences were as follows: 1) forward primers, $5^{\prime}$ TTT CAC TTG GCA TTA CTC AAA AG-3' and 5'CAA TGC CTA AGT TGG ATT CAG GTT G-3', and

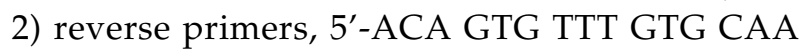


ATC CTG AGA C-3' and 5'-ATA CTC WAG GCC TAY AGC CTG TGG T- $3^{\prime}$.

The PCR reaction mixture $(50 \mu \mathrm{l})$ contained $10 \times$ LA PCR Buffer II, $2.5 \mathrm{mM} \mathrm{MgCl} 2$, dNTP mixture, 2.5 U LA-Taq polymerase (Takara), $0.25 \mu \mathrm{M}$ each of the forward and reverse primers and $1 \mu \mathrm{l}$ of the RT reaction. PCR amplification was performed in a Perkin Elmer DNA thermal cycler (Model 2400), under the following conditions: denaturation at 94 $C$ for 5 min was followed by 40 cycles of denaturation at $94 \mathrm{C}$ for $1 \mathrm{~min}$, annealing at $50 \mathrm{C}$ for $2 \mathrm{~min}$, extension at $72 \mathrm{C}$ for $2 \mathrm{~min}$, and a final extension at $72 \mathrm{C}$ for $7 \mathrm{~min}$. After PCR amplification, an aliquot of the reaction mixture was loaded onto $1 \%$ TAE agarose gel and electrophoresed; the products were stained with ethidium bromide .

\section{Sequencing and sequence analysis}

The PCR-amplified equine myostatin cDNA fragments were cloned into pGEM-T vector (Promega, WI) and sequenced using a ThermoSequenase Cycle Sequencing kit (Amersham-Pharmacia, Kyoto) and a DSQ-2000L DNA sequencer (Shimadzu, Kyoto). Analyses of the obtained sequence were performed using DDBJ/Genbank databases and the BLAST search system as well as Genetyx software (Software Development, Tokyo) .

\section{Antibody}

A custom-synthesized partial peptide of myostatin, QKYPHTHLVHQANPRGSAGPC (Sawady, Tokyo) (1 mg), was dissolved in $1 \mathrm{ml}$ DMSO (Sigma) and mixed with key hole limpet hemocyanin (KLH) and a cross-linker, mmaleimidobenzoyl-N-hydroxy- succinamide (MB), under a nitrogen stream. After incubation for $3 \mathrm{~h}$ at room temperature, the mixture was frozen and stored at $-20 \mathrm{C}$ until use. The conjugate (100 mg) was emulsified with Freund's complete adjuvant (FCA) $(1.5 \mathrm{ml}$; CAPPel $)$ and injected into 20 subcutaneous parts of each of 3 rabbits used for the experiments. Subcutaneous injections of the antigen emulsified in Freund's incomplete adjuvant (FIA) (DIFCO) were given 3 weeks later. Booster injections of the FIA-emulsified antigen were repeated at an interval of 1 week. The antibody titers were checked regularly by ELISA assay method. When sufficiently high titers were obtained, the rabbits were exsanguinated and serum was collected and stored at $-20 \mathrm{C}$ until use. The details of the antibody are described elesewhere [13].

\section{Western blotting}

For Western blot analysis, $5 \mathrm{ml}$ of horse blood serum were purified using Molcut-L LGC (Millipore) in an ice bath and were mixed vigorously with a buffer containing $100 \mathrm{mM}$ Tris$\mathrm{HCl}$ (pH 6.8), 4\% SDS, 12\% 2-mercaptoethanol and $20 \%$ glycerol. Skeletal muscles were homogenized with an Ultraturrex homogenizer (M. Zipper $\mathrm{GmbH}$, Switzerland) in a buffer containing $50 \mathrm{mM}$ Tris-HCl (pH 6.8), 2\% SDS, 6\% 2-mercaptoethanol, $10 \%$ glycerol and heated at $65 \mathrm{C}$ for $10 \mathrm{~min}$. The denatured protein extracts were separated on a $10 \%$ polyacrylamide-SDS gel by electrophoresis and transferred to a nitrocellulose membrane (Clear blot membrane-P; Atto, Tokyo). The membrane was soaked in $1 \%$ blocking buffer (Boehringer Mannheim, Tokyo) and then incubated with purified myostatin antibodies diluted with PBS (1: 1000) at room temperature for $1 \mathrm{~h}$. The membrane was washed 3 times for 5 min each with PBS and incubated with the 2nd antibody, goat anti-rabbit IgG conjugated to horse radish peroxidase (American Qualex, CA), for $1 \mathrm{~h}$ at room temperature. The membrane was washed for 15 min with PBS 3 times and HRP activity was detected using diaminobenzidine (DAB; Wako, Osaka) .

\section{Results and Discussion}

We isolated and cloned myostatin cDNA from equine (Thoroughbred) skeletal muscles by an RTPCR method (Fig. 1). The base sequence of the entire coding region was determined (Fig. 2). Alignment of the equine myostatin cDNA sequence to those of other species, confirmed the highly conserved nature of myostatin genes among the species so far examined (Fig. 3). In Fig. 4, the deduced amino acid sequence of the equine myostatin peptide is aligned with those of other species. Four amino acid positions were unique to the equine myostatin: $\mathrm{Val}^{15}$ instead of Met, $\mathrm{Leu}^{18}$ instead of Val or Ala, Ala ${ }^{201}$ instead of Thr, Arg ${ }^{244}$ instead of Gly or Glu in other species (Fig. 4). Altogether equine myostatin exhibited a high degree of homology (94.7-97.3\%) to myostatins of 
other species so far reported in the literature (Table 1).

The equine myostatin possesses, like myostatins of other species, the TGF- $\beta$ motif (298-313; IIAPKRYKANYCSGEC ) and the EF-hand motif (99-111; DDSSDGSLEDDDY) (Fig. 4). A putative proteolytic processing site, $R^{263} S R R^{266}$, is indicated in Fig. 4. The myostatin precursor protein is cleaved at this site to give rise to a mature protein [1].

The hydropathy plots of myostatin revealed alternating hydrophobic and hydrophilic regions and exhibited an almost identical pattern to those of other species, indicating that the structural and functional features of myostatins are highly conserved among species (data not shown).

Western blot analysis under reducing conditions of the equine skeletal muscles yielded 3 immunoreactive bands at estimated molecular masses of 26, 45 and $50 \mathrm{kDa}$ (Fig. 5). The 26 and 50 $\mathrm{kDa}$ bands corresponded to the molecular sizes of mature myostatin protein and unprocessed precursor myostatin proteins, respectively, so far reported in the literature (in sheep [14]; in humans [15]). The identity of the $45 \mathrm{kDa}$ band remains to be clarified. However, on the basis of the amino acid sequence deduced from the cDNA base sequence, the estimated molecular mass of the precursor and mature myostatin proteins in different species are approximately 43,000 and 13,000, respectively (data not shown). The discrepancy between the molecular size calculated from the deduced amino acid sequence and that of the immunologically detected bands may be due to differences in the post-translational modifications such as glycosylation of myostatin proteins [11].

One possible explanation for the presence of 45 $\mathrm{kDa}$ band in the horse serum is that it might represent a non-glycosylated myostatin molecule. McPherron et al. [1] have detected a mature myostatin protein of $13 \mathrm{kDa}$ on Western blot analysis of $\mathrm{CHO}$ cell extracts under reducing conditions. Wehling et al. [11] suggested that the difference between the $13 \mathrm{kDa}$ and the $26 \mathrm{kDa}$ immunoreactive protein may be accounted for by the difference in the post-translational modifications mentioned above [11] .

Our results, therefore, strongly indicate that mature and unprocessed precursor myostatin proteins co-exsist in adult equine skeletal muscles. Judging from the intensities of the bands, the

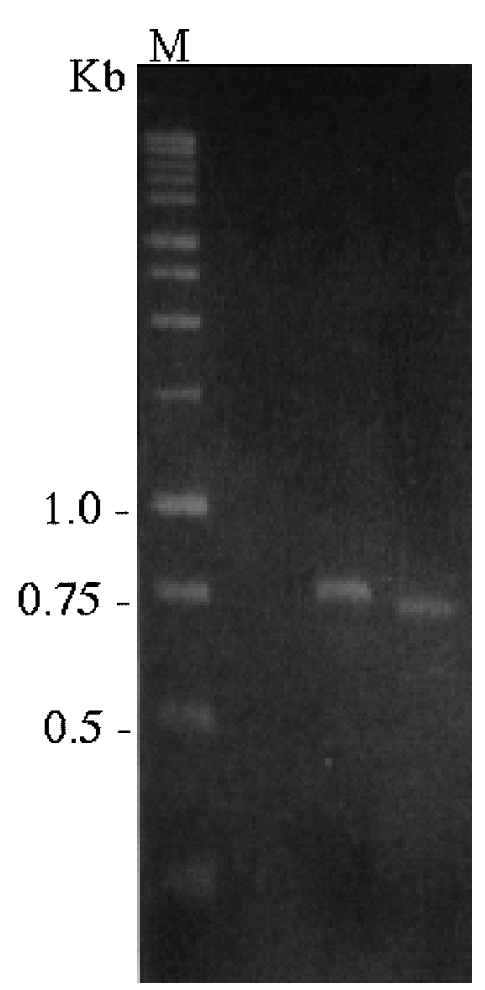

Fig. 1. PCR amplification of equine myostatin cDNA using two primer sets specific to the myostatin sequences. The PCR products were electrophoresed on 1.0\% TAE agarose gel. Each band was excised from the gel, purified and ligated into pGEM-T vector (Promega) for subsequent sequencing.

expression levels of mature myostatin were much lower than those of the precursor protein in equine skeletal muscles.

A surprising finding was made when we carried out Western blot analysis of equine sera of 2 independent breeds, Thoroughbred (a typical imported breed) and Kiso-uma (a breed native to Japan), for the possible presence of myostatin. As shown in Fig. 6, in the equine sera, a $50 \mathrm{kDa}$ band matching the size and immunoreactivities of unprocessed precursor myostatin in the skeletal muscle was detected (Fig. 5), but no band was seen in the $26 \mathrm{kDa}$ regions representing mature myostatin.

Previously, the presence of myostatin-like protein as detected by Western blot analysis in the sera of HIV-infected men was reported by Gonzalez-Cadavid [15]. This was the first report describing the expression of myostatin or myostatin-related protein in the serum. However, recently Wehling et al. [11] questioned the 


\begin{tabular}{|c|c|c|c|c|c|c|}
\hline AAGTA & $\mathrm{AA}$ & GAGCA & AAAGATTGAA & СTGATTTTAA & AATCATGCI & \\
\hline & TСTGTTTA & TATTTACCTG & TTTGTGCTGA & TTCTTGCTGG & TCCAGTGGAT & \\
\hline СAAATGAGA & ACAGCGAGCA & AAAAGAAAAT & TGGAAAAAG & AGGGGCTGTG & CAATGCATGT & 80 \\
\hline ETTGGAGAC & AAACACTAA & TCTTCAAGA & TAGAAGCCA & AAAAATTCA & АTССТCAGT & 240 \\
\hline CGCC & GCC & ТССТААСАТС & GCAAAGATG & TATTAG & АCTTTTGCCC & 300 \\
\hline CTC & GGA & ACTGATTGAT & SATG & & GACAGCAGT & 360 \\
\hline ATGGCTCTT & GGAAGATGA & TGATTACCAC & CGACGACGG & AACAAT & ACCATGCCT & 420 \\
\hline 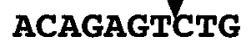 & CAAT & GCAAGTGGAA & GAAAACCCA & & СТTTАААТTT & 480 \\
\hline GCTCTAAAA & :ACAATACAA & TAAAGTAGTA & AAGGCCCAAC & TA & TCTGAGACCC & 540 \\
\hline AAGACTC & CTACAACAGT & GTTTGTGCAA & TCCTGAGAC & CC & AGAC & 600 \\
\hline ACAAGGT & TACTGGAAT & CCGATCTCTG & $\triangle A A C T T G A C A$ & GG & CGCTGGTATT & 660 \\
\hline GGCAGAGCA & TGATGTGAA & GACAGTGTTG & CAAAATTGGC & CE & TGAA & 720 \\
\hline GGCATTG & AAATCAAAGC & AGATGAG & ATGGTCATG & GT & АССТТСССА & 780 \\
\hline CAGGAG & AGATGGGCT & GAATCCATTT & TAGAAGTTA & GG & CAAAA & 840 \\
\hline GATCCAGAA & AAGATTTTG & ACTTGACTGT & ATGAGCACT & CCA & TCGATGCTGT & 900 \\
\hline TACCCTC & TAACTGTGGA & TTTTGAAGCT & TTGGATGGG & AAT & TGCACCCAAA & 960 \\
\hline TATAAGG & САATTACTG & CTCTGGAGAG & GTGAATTTG & TAT & АAATATCCT & 1020 \\
\hline 'CATC & ГGTACACCA & AGCAAACCCC & GAGGTTCAG & CCTG & CGTACTCCC & 1080 \\
\hline & & & & & TGGG & 140 \\
\hline CCAG & AGT & GCTGT & GGTGCTCAT & & TCAT & 1200 \\
\hline ג ג מי & & $\mathrm{CCCCT}$ & САATTGTG & & TGT & 1257 \\
\hline
\end{tabular}

Fig. 2. Nucleotide sequence of equine myostatin cDNA. The Open Reading Frame sequence (Hosoyama et al., DDBJ accession no. AB033541) is indicated by bold capital letters and the untranslated regions are represented by plain capital letters. Translation initiation (ATG) and stop codons (TGA) are indicated by bold italics. Arrowheads indicate exon-exon boundaries.

authenticity of the myostatin-immunoreactivities described by Gonzalez-Cadavid [15], on the basis of the discrepancy in the molecular mass.

The $50 \mathrm{kDa}$ band presently detected in equine sera coincided with the molecular mass of the band detected in the equine skeletal muscles and also with that of precursor myostatin proteins in sheep reported by Sharma et al. [14]. Therefore, we tentatively concluded that myostatin precursor proteins are present in adult equine serum at sufficiently high levels as detected by Western blot analysis.

Interestingly, before the myostatin gene was identified, Gerrard and Judge [16] had demonstrated that in murine L6 myoblasts, the induction of cell proliferation took place in media supplemented with serum from double-muscled cattle [16], suggesting that in the control serum of normal cattle, a factor suppressing proliferation might be present.

The molecular identity and the biological significance of serum myostatin immunoreactivities remain to be clarified. However, they might reflect the physiological status of skeletal muscles under varying degrees of loading in physical exercises. Further characterization of the presently-described serum myostatin immunoreactivities is currently in progress at our laboratory.

\section{Acknowledgements}

Our thanks are due to Assoc. Prof. Tatsuya Takizawa, Lab. Develop. Reprod. Biotechnol., Azabu University, for his advice and help offered to us during the course of the experiments. We are much indebted to Prof. H. Fujitani and Lecturer Dr. M. Murakami, Laboratory of Molecular Biology, Dept. Veterinary Science, Faculty of Veterinary Medicine and Life Sciences, Azabu University for allowing us to use his facilities, and expert advice. We thank Prof. Michio Takahashi and Prof. Tohru Sawasaki of the Bio-Animal Science Experimental Station, The University of Tokyo, for providing us with blood samples from Thoroughbred horses. We also thank Prof. Mitsuko Masui and Prof. 




Fig. 3. Alignment of the nucleotide sequences of equine, bovine (McPherron and Lee, 1997, GenBank no.AF019620), baboon (McPherron and Lee, 1997, GenBank no.AF019619) and human (Gonzalez-Cadavid et al., 1998, GenBank no. AF104922) myostatin ORFs. Dots denote identical nucleotides among the species. 


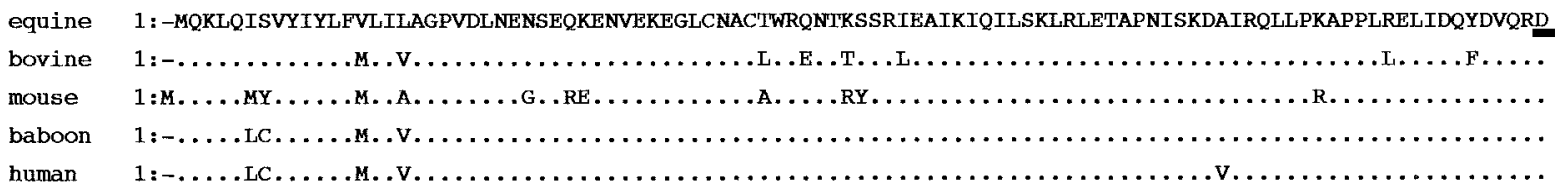

equine 101 :DSSDGSLEDDDYHATTETIITMPTESDLLMQVEGKPKCCFFKFSSKIQYNKVVKAQLWIYLRPVKTPTIVFVQILRLIKPMKDGTRYTGIRSLKLDMNPG

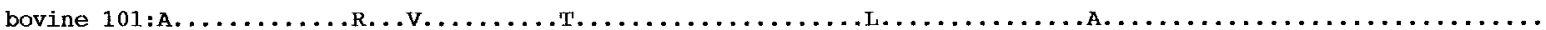

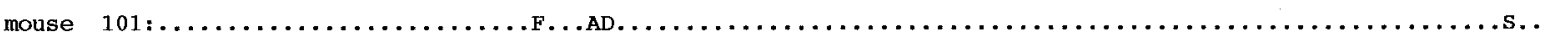

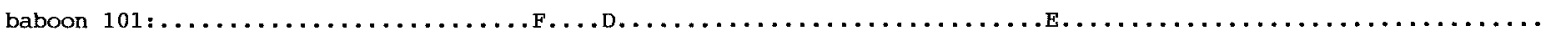

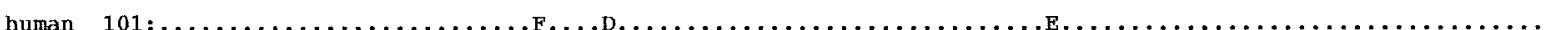

equine 201 : AGTWQSIDVKTVLQNWLKQPESNLGIE IKALDENGHDLAVTFPRPGEDGL_NPFLEVKVTDTPKESREDFGLDCDEHSTESRCCRYPLTVDFEAFGWDWII

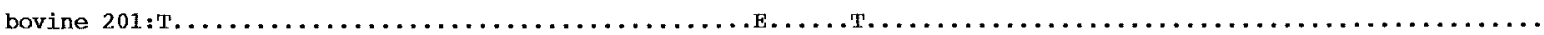

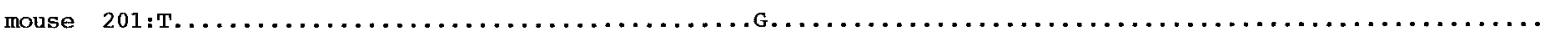

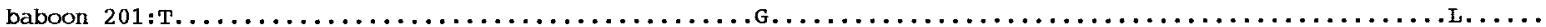

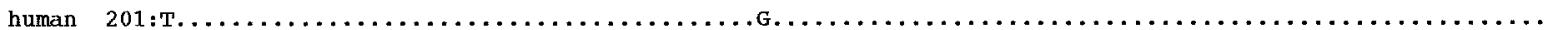

equine 301 :APKRYKANYCSGECEFVFLQKYPHTHLVHQANPRGSAGPCCTPTKMSPINMLYFNGKEQIIYGKIPAMVVDRCGCS

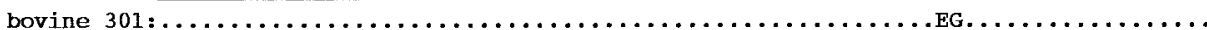

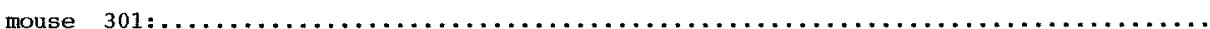

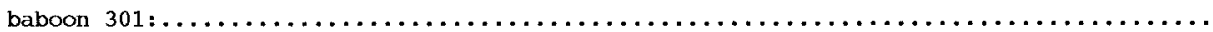

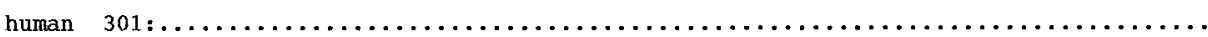

Fig. 4. Alignment of amino acid sequences of equine, bovine, murine, baboon and human myostatins. Dots denote identical amino acids among the species. TGF- $\beta$ and EF-hand motifs are underlined. A putative proteolytic processing site is framed.

Table. 1. Homology scores of myostatin protein among different mammalian species

\begin{tabular}{llllll}
\hline equine & $100 \%$ & & & & \\
bovine & $94.9 \%$ & $100 \%$ & & & \\
mouse & $95.5 \%$ & $92.5 \%$ & $100 \%$ & & \\
baboon & $97.3 \%$ & $94.1 \%$ & $96.3 \%$ & $100 \%$ & \\
human & $97.3 \%$ & $94.1 \%$ & $96.3 \%$ & $99.5 \%$ & $100 \%$ \\
& equine & bovine & mouse & baboon & human \\
\hline
\end{tabular}

Mitsuaki Ohta, Lab. Animal-Human Relations, Azabu University, for allowing us to collect blood samples from their Kiso-uma horses.

\section{References}

1. McPherron AC, Lawler AM, Lee S-J. Regulation of skeletal muscle mass in mice by a new TGF- $\beta$ superfamily member. Nature 1997; 387: 83-90.

2. Varga L, Szabo G, Darvasi A, Muller G, Sass M, Morris M. Inheritence and Mapping of Compact (Cmpt), a new mutation causing hypermuscularity in mice. Genetics 1997; 147: 755-764.

3. Grobet L, Martin LJR, Poncelet D, Priottin D, Brouwers B, Riquet J, Schoeberlein A, Dunner S, Menisseir F, Massabandam J, Fires R, Hanset, R, Georges $\mathbf{M}$. A deletion in the bovine myostatin gene causes the double-muscled phenotype in cattle. Nat Genet 1997; 17: 71-74.

4. Smith TPL, Lopez-Corrales N, Kappes SM, Sonstegard TS. Myostatin maps to the interval containing the bovine mh locus. Mamm Genome 1997;
8: 742-744.

5. Grobet L, Poncelet LJR, Brouwers B, Pirottin D, Michaux C, Mennissier F, Zanotti M, Dunner S, Georges M. Molecular definition of an allelic series of mutations disrupting the myostatin function and causing double-muscling in cattle. Mamm Genome 1998; 9: 210-213.

6. Kambadur R, Sharma M, Smith TPL, Bass JJ. Mutations in myostatin (GDF-8) in double-muscled Belgian blue and Piedmontese cattle. Genome Res 1997; 7: 910-915.

7. McPherron AC, Lee S-J. Double muscling in cattle due to mutations in the myostatin gene. Proc Natl Acad Sci USA 1997; 94: 12457-12461.

8. Ji S, Losinski RL, Cornelius SG, Frank GR, Willis GM, Gerrard DE, Depreux FFS, Spurlock ME. 


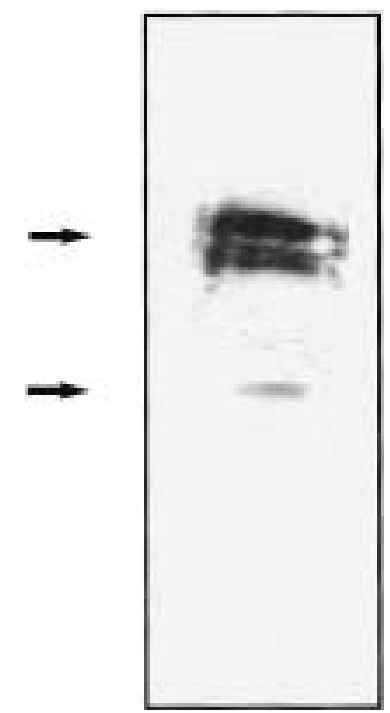

Fig. 5. Western blot analysis of the soluble fractions of equine skeletal muscle homogenates. After electrophoresis, the membranes were blotted, and probed with anti-myostatin antibodies. The positions of myostatin precursor protein $(50 \mathrm{kDa})$ and mature myostatin $(26 \mathrm{kDa})$ are indicated by arrows. The immunochemically stained bands coincide in size to unprocessed and processed myostatin proteins, respectively. Two bands could be resolved in the high molecular weight precursor proteins of equine myostatin.

Myostatin expression in porcine tissues: tissue specificity and developmental and postnatal regulation. Am J Physiol 1998; 275: R1265-R1273.

9. Lee S-J, McPherron AC. Myostatin and the control of skeletal muscle mass. Curr Opin Genet Dev 1999; 9: 604-607.

10. Bullough WS. The control of mitotic activity in adult mammalian tissues. Biol Rev 1962; 37: 307-342.

11. Wehling M, Cai B, Tidball JG. Modulation of myostatin expression during modified muscle use. FASEB J 2000; 14: 103-110.

12. Carlson CJ, Booth FW, Gordon SE. Skeletal muscle myostatin mRNA expression is fiber-type specific and increases during hind limb unloading. Am J Physiol 1999; 277: R601-R606.

13. Kawada S, Tachi C, Ishii N. Content and localization of myostatin in mouse skeletal muscles during aging, mechanical unloading and reloading.

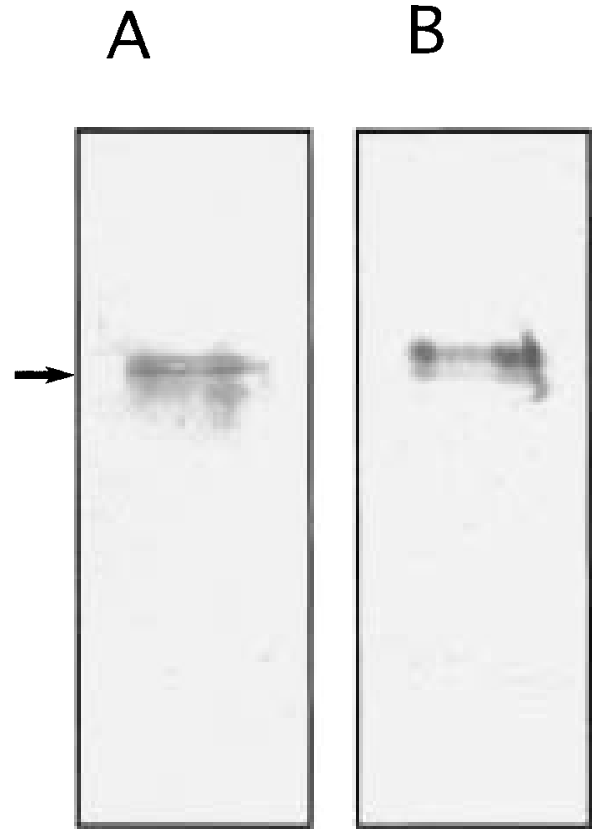

Fig. 6. Western blot analysis of the equine serum. The collected sera were electrophoresed, blotted, and probed with anti-myostatin antibodies. The position of myostatin unprocessed precursor protein is indicated by an arrow (50 kDa). Immunoreactivities were detected only in the region corresponding in size to the unprocessed myostatin protein. The same myostatin immunoreactivities were detected in both Thoroughbred(A) and Kiso-uma (B) horses.

J Muscle Res Cell Motil (in press).

14. Sharma M, Kambadur R, Matthews KG, Somers WG, Devlin GP, Conaglen JV, Fowke PJ, Bass JJ. Myostatin, a transforming growth factor- $\beta$ superfamily member, is expressed in heart muscle and is upregulated in cardiomyocytes after infarct. $J$ Cell Physiol 1999; 180: 1-9.

15. Gonzalez-Cadavid NF, Taylor WE, Yarasheski K, Sinha-Hikim I, Ma K, Ezzat S, Shen R, Lalani R, Asa S, Mamita M, Nair G, Arver S, Bahasin S. Organization of the human myostatin gene and expression in healthy men and HIV-infected men with muscle wasting. Proc Natl Acad Sci USA 1998; 95: 14938-14943.

16. Gerrard DE, Judge MD. Induction of myoblast proliferation in L6 myoblast cultures by fetal serum of double-muscled and normal cattle. J Anim Sci 1993; 71: 1464-1470. 